\title{
SOCIAL-COMMERCIAL INTERCONNECTION: LESSONS FROM BANK MUAMALAT INDONESIA \& BAITULMAAL MUAMALAT AFFILIATION
}

\author{
Ai Nur Bayinah ${ }^{1}$, Muhammad Said $^{2}$ and Munzier Suparta ${ }^{3}$ \\ ${ }^{1}$ STEI SEBI, Indonesia, ai.nur.bayinah@sebi.ac.id \\ ${ }^{2}$ UIN Jakarta, Indonesia, m.ms4id@gmail.com \\ ${ }^{3}$ UIN Jakarta, Indonesia, mundziersuparta@yahoo.com
}

\begin{abstract}
This research aims to explore the model of interconnection between the Islamic Bank and Zakat Management Organisation, as the two represent the implementation of Islamic economics in Indonesia. Using the Group Method of Data Handling (GMHD) tool to discern the strength of the relationship between the two representative entities, Bank Muamalat Indonesia and Baitulmaal Muamalat, it also followed the hyper postphenomenology approach to sharpen the result by obtaining essential confirmation from key informants with respect to determining the ideal model. The result showed a robust and reciprocal correlation between the account variables and its influence was statistically significant. Furthermore, it was interpreted as an effort to improve the image of the banking system while providing added value, forms of corporate responsibility and a spirit of service to customers. The results led to convergence on the formulation of the ideal model, which depends on the moral intentions of the owners of capital, government alignment and the literacy of directors, control needs and public awareness. Thus, it bridges the findings of previous studies and recommends a model that inseparable moral economic instruments.
\end{abstract}

Keywords: Interconnection, Bank, Zakat, Social, Commercial.

JEL classification: A13; B55; C45; D64; O35.

\author{
Article history: \\ Received : October 11, 2020 \\ Revised : January 25, 2021 \\ Accepted : : March 8, 2021 \\ Available online : May 20, 2021
}

https://doi.org/10.21098/jimf.v7i2.1339 


\section{INTRODUCTION}

\subsection{Background}

The current pandemic situation has forced Islamic banks to re-strengthen their foundations and strategies. Moreover, these banks are not completely immune to the impacts of macroeconomics shocks (Kasri, Arundina, Indraswari, \& Prasetyo, 2017) that may occur as an impact of the weak handling of Covid-19.

Referring to the history of Islamic banks, the main reason for establishing this type of institution was to avoid usury (Kar, Nazhoglu, \& Agir, 2011). Islamic banks combine the monetary and real sectors that were previously separate in the conventional interest-based financial services scheme and replace them with a murabahah contract for transactions as a solution (Siddiqi, 2006).

However, it is difficult to avoid the stiff competition from conventional banking at both a local and global level, which even tends to dominate. Mufraini (2013), among others, proved this empirically by taking a sample of 87 Islamic banks in Asia and demonstrating that Islamic banks remain the same as conventional banks and tend not to be fully compliant with Islamic values.

In Indonesia, there are more than 10 Islamic banks but only 7 of these pay zakat. The rest lean more towards the function of collecting zakat paid by the public (Masra, Saleh, \& Hamid, 2020). The relationship between Islamic banks and zakat management organisations as a part of the Islamic economic system is thus a high priority for discussion. In Surah al-Baqarah verse 276, Allah eliminates usury and makes alms fertile. How are the two related? Will alms eliminate the practice of usury? Or does this constitute an anti-usury financial transaction that will encourage the higher growth potential of alms? Or even the possibility of the two working hand in hand?

Based on its current development, the Islamic financial industry in Indonesia has yet to reach an ideal point in terms of its expected potential. Islamic banking has yet to attain a one-tenth share of the industrial market (OJK, 2019). Meanwhile, for zakat, which had been predicted to potentially amount to more than 200 trillion rupiahs (BAZNAS Center of Strategic Studies, 2019), only about 10 trillion, or five per cent, has been recorded in the collection (BAZNAS, 2019).

There may be many factors at play here, but this paper aims to examine the situation from an alternative perspective to discern the pattern of the relationship and how closely the two entities are related. Indeed, are the two interconnected? Therefore, this research could provide a clear explanation of the various factors that may be relevant in terms of optimising the two entities to support economic development in Indonesia.

The establishment of zakat institutions in private companies has illustrated a new trend of philanthropic practice in Indonesia. The experiences of Bank Muamalat Indonesia (BMI) and BSM provide examples of how to practise zakat on company assets (Latief, 2013). While different methods are used to calculate trade zakat, the chosen method should be acceptable as long as it respects Islamic principles (Tajuddin \& Bahari, 2019). Currently, there are 572 Zakat Management Organisations, comprising 1 (one) National BAZNAS, 34 Provincial BAZNAS, 456 Regency/City BAZNAS, 26 National LAZ, 18 Provincial LAZ and 37 Regency/ City LAZ. Meanwhile, only 1 National Zakat Institution has an affiliation with an Islamic Bank, namely Baitulmaal Muamalat (BAZNAS, 2019). 
In terms of zakat collection, Islamic banks collect only a marginal amount, accounting for no more than $2 \%$ of the national zakat collection (BAZNAS, 2019; Bank Muamalat Indonesia, 2019; Bank Syariah Mandiri, 2019). It is argued that the payment of these alms is generally considered an obligation that is imposed on the business partners of the Islamic bank. Nevertheless, as business entities in their own right, Islamic banks are also required to pay zakat without exception (Ismail \& Khir, 2010).

It seems that Islamic banks need to continue the process of transformation by putting into action the next verse of Al-Baqarah verse 276. Several interpretations of this verse explain that usury, which is considered to be able to increase wealth, has been negated by alms (Shihab, 2000; Abdurrahman, 2008), as in the sense of a gift that does not expect rewards. Instead, Allah promises that it will grow and provide more benefit for people. As Suharto (2017) states, both in its commercial and social aspects, it can play a role in stabilising the financial system.

According to Hassan and Lewis (2007), many people do not fully understand the purpose of this entity, which makes Islamic banking interesting to study. Since it aims to serve the Muslim community, this system of banking also emphasises Islamic credentials by collecting and distributing zakat. Tripp (2006) even combined zakat and the efforts to eradicate usury as an inseparable moral economic instrument. Based on the same motivation of monotheism, according to Choudhury and Harahap (2009), both are driven to be more productive and develop, with wider operational scope for social and economic connectivity (Choudhury, 2013). Dusuki (2008a) asserts that this goal is higher than that found in conventional banking as it involves running a mixed financial system (hybrid), with two dimensions at once, namely the world and the hereafter, as explained by Asutay (2007, p. 172), and referred to by Rudnyckyj (2010) as a Spiritual Economy.

As a result of this hybrid system, Islamic banks do not focus solely on profit (profit-driven). Instead, their success is highly dependent on the integration of social values within the mechanisms of financial innovation created (Dusuki, 2008b). If the Islamic bank moves away from one of the above-mentioned dimensions, then, as stated by critics Haniffa and Hudaib (2010), the Islamic Financial Institution (IFI) is considered to have distorted its sacred intention to help the Muslim community, especially in the fight against usury and instead becomes merely a secular goal to compete with conventional banking. Therefore, it is important in this study, as a novelty, to provide a more detailed explanation of how these practices of social and commercial interconnection occur. The study also provides material for evaluation in improving the future performance of Islamic financial institutions following the mandate of their founders.

\subsection{Objective}

Theoretically, Islamic banks and the Zakat Management Organisation (ZMO), as the two representative institutions of the Islamic economic system, have a tight relationship. Unfortunately, the two institutions operate separately. In the scope of research, both have only been partially analysed, and a strong correlation has not yet been found with respect to each institution supporting the development of other industries (Siddiqi, 2006). Therefore, this research aims to understand the 
interconnection of the institutions as part of a relational network that connects the two.

This research comprises several stages: firstly, it aims to find empirical evidence of interconnections; second, it describes the essence of the network that links the two institutions, and finally, it explores the significant factor(s) to create the best linkage and integration for the two institutions. All of this is necessary to strengthen the roles and optimise the development of both institutions in the future.

The remainder of the paper is structured as follows. Section II reviews the background theory and previous studies. Section III explains the data, hypothesis testing of the interconnection and the method. Section IV analyses the result and social-commercial interconnection. Finally, Section V concludes the study and provides recommendations.

\section{LITERATURE REVIEW}

\subsection{Background Theory}

Rahman (1995, pp. 339-346) asserted that no bank or banking policy can operate successfully in a country unless the people put their trust and confidence in the credibility of the bank. Kuran (1997) explained that the institution can continue to improve its performance and dismiss the allegations of parties who consider its presence to be merely a business matter and based on identity politics. Islamic banks, therefore, need to continue to prove the great vision that Chapra (2009) calls Islamic Ethics, to become not just an ordinary bank (i.e. to go beyond banking).

Community contributions such as zakat have never been included in the conventional perspective as one of the drivers of the economy. However, in Islam, it plays an important economic role, both in the classical view according to AlHaritsi (2006, pp. 285-290) and in modern times as conveyed by Siddiqi (2005, p. 18). The role of driving economic growth is given more in the commercial sector such as banking. This includes Islamic banking, which Yusof and Bahlous (2013) researched as showing both causalities, although in Indonesia, according to Rusydiana (2009), the results were not similar.

Egypt was the first to integrate banking institutions and the use of donated funds in the form of zakat in a model called Nasser Social Bank. Bremer's evaluation of the impact of zakat on development (Z4D) in the country shows that the application succeeded in reforming traditional and static management models to become a systematic undertaking by using Zakat as a powerful Islamic financial tool to improve community welfare and reduce poverty (Bremer, 2013).

According to Chapra (2000, p. 274), the distribution of zakat funds must be a permanent supplement for those who cannot support themselves through business assistance. It also provides the training tools, equipment and other materials needed to earn sufficient income. Zakat may also increase the availability of funds for investment. The expansion of this role therefore adds new spaces that have not yet been touched. Theoretically, there were reasons for this, which had the potential to become the background of this relational network. They included Intermediation Theory, then Stakeholder Theory, Institutional Theory, Social Network Theory, Theory of Altruism in Networks, and finally the concept 
of the Islamic Perspective on Altruism. This multi-level theoretical model is used to explore the various factors that describe the interconnection network of those institutions.

\section{Intermediation Theory}

Financial intermediation is not yet considered able to provide a sufficient understanding of the current dynamic conditions, as suggested by Scholtens and Wensveen (2003). Hence, this research is vital in bridging this gap. Despite having different basic roles, Islamic bank intermediation and ZMO are interconnected in the target client in a way that is different from the dynamics in the community and both institutions. According to Levin, Loayza, and Beck (2000), an exogenous component in the form of the development of financial intermediation in a better financial system will facilitate the external financing faced by companies.

\section{Stakeholder Theory}

Analysis of the interconnection of Islamic banks and ZMOs can also be approached from the perspective of stakeholder theory, with two main questions as a focus: the company's and the management's responsibilities towards stakeholders. An enlightened stakeholder theory is then formed by specifying long-term value maximisation as the goal of the company. This would solve problems that arise due to the layered objectives that accompany traditional stakeholder theory (Jensen, 2001). Furthermore, instrumental stakeholder theory is developed to give an arrow of integration of business and social areas (Jones, 1995). Thus, it is interesting to examine how Islamic banks, which theoretically have a social and commercial hybrid function, might explain the suitability of their practice with the objectives adopted by the company.

\section{Institutional Theory}

Campbell (2007) uses institutional theory to understand corporate social behaviour. This theory is important as a basis for analysis in order to determine where Islamic banks and OMZ are interrelated, in addition to the policies that underlie the relationship between the two. In terms of initiating institutional change, lessons can also be taken from the change process, including transnational trends (Dacin, Goodstein, \& Scott, 2002).

This theory can be classified into 4 (four) groups: instrumental theory, political theory, integrative theory and ethical theory. In practice, however, each corporate social responsibility theory represents profit, political performance, social demand and ethical values in a related way, and suggests the development of new theories by looking at business and community relationships that are better able to integrate the four dimensions (Garriga \& Melé, 2004). 


\section{Social Network Theory}

According to Freeman, there is no such thing as a stakeholder theory; it is merely a genre that is quite rich. The concept of the stakeholder can be used to create more fine-grained analyses that combine business and ethics and apply to more than just commercial interests (Freeman, 1994). Rowley then constructed stakeholder demands as interdependent and predicted the way in which organisations respond to the simultaneous influence of these multiple stakeholders (Rowley, 1997). Social Network Theory is also known as social or communication network analysis (Dunn, 2016). To establish the connectivity between banking and zakat, research needs to be conducted to provide evidence that interfirm networks can be deliberately designed to integrate resources from both within and outside the boundaries of companies, from which emerges a unique organisational capability (Lorenzoni \& Lipparini, 1999).

\section{Theory of Altruism in Networks}

Altruism is another theory that may be related to the interconnection of Islamic banks and ZMOs. This altruistic behaviour, based on two stages of protocol experimental, observes and finds that social distance and network position are the determining factors. Although various individual factors and their relationships were controlled, network factors made a significant contribution to altruism. Individuals thus tend to be more altruistic towards social members who are more connected in the network (Curry \& Dunbar, 2011). The first analysis of altruism in networks was carried out by Bourles and Bramoulle (2013).

\section{Islamic Perspective on Altruism}

In conventional theory, altruistic behaviour, as previously explained, is influenced by social distance and network position between the parties. Meanwhile, in Islam, according to Az-Zuhaili (2011), it has its own principles. Altruistic behaviour from an Islamic perspective is also related to views of social solidarity. In Islam, all elements of Muslim society are bodies that support each other. As a consequence, individual happiness cannot be attained except in the presence of public welfare.

\subsection{Previous Studies}

At the end of the $20^{\text {th }}$ century, the idea of social investment began to find legitimacy and make a productive contribution. Both the World Bank and the Organisation for Economic Development and Cooperation (OECD) played an important role in its development in the mid-1990s. A decade later, these two organisations assumed a broader orientation and focused on the concept of inclusive growth (Mahon, 2019). Financial intermediation organisations continue to grow dynamically in line with the needs of people and become interconnected to offer the best service. Various studies have provided an insight into the interconnection journey between financial institutions (Meydia, 2013; Muljadi, 2017; Rahayu \& Pranowo, 2012).

Islamic banking represents a new wave of corporations whose social goals are as important as generating profit (Zafar \& Sulaiman, 2019). Jouti (2019) used a 
theoretical approach in building sustainable ecosystems through existing social initiatives and practices. But Islamic banking needs to employ more innovative efforts in order to integrate sustainable and responsible investment to help society (Ahamat, 2017).

However, current practice within Islamic banking has yet to address moral issues in promoting a balance of social and economic justice (Nor, 2016). Social roles are not included in the variables that are involved in boosting Islamic bank growth (Cham, 2018). It has been found that Islamic finance institutions tend to be defensive when it comes to corporate social responsibility, with only $27.8 \%$ involved in this in practice. Yet all Islamic banks carry out the obligation of Zakah, and most provide charitable loans to help the poor (Askari, Iqbal, Krichene, \& Mirakhor, 2010, pp. 197-199).

Asutay recommended the establishment of a bridging institution to moderate the social failures of Islamic banks and the potential zakat in a special entity such as Bank Dana Zakat, to serve the social needs and economic empowerment of Muslim society (Asutay, 2012). Dakhori, Luth, Ruba'i, and Syafa'at (2014) captured this idea as a basis for the rationalisation of a Zakat Bank in Indonesia that has 2 (two) functions, serving as both an intermediary for business funding and also for religious social intermediaries. Rahman (2007) and Siswantoro (2008) also conducted studies related to the provision of financial assistance for micro, small and medium enterprises (MSMEs), which is permitted by Law No. 38 of 1999 on a productive basis.

\subsection{Conceptual Framework}

This study uses a multi-level theoretical model to create a conceptual framework for the interconnection of Islamic banks and zakat management organisations (ZMO). Chapra (2000) outlined that the reorganisation of the existing financial system and the revitalisation of the empowerment of social assistance in the form of zakat comprise two of the four main elements of restructuring that are important and of great concern within Islam. Yet this is often misunderstood and ignored. Thus, there is an urgent need for improvement in this basic element because it implies the formulation of a policy package to realise Islamic objectives (maqashid al-Syari'ah). Figure 1 summarises the conceptual models from the abovementioned theories: 


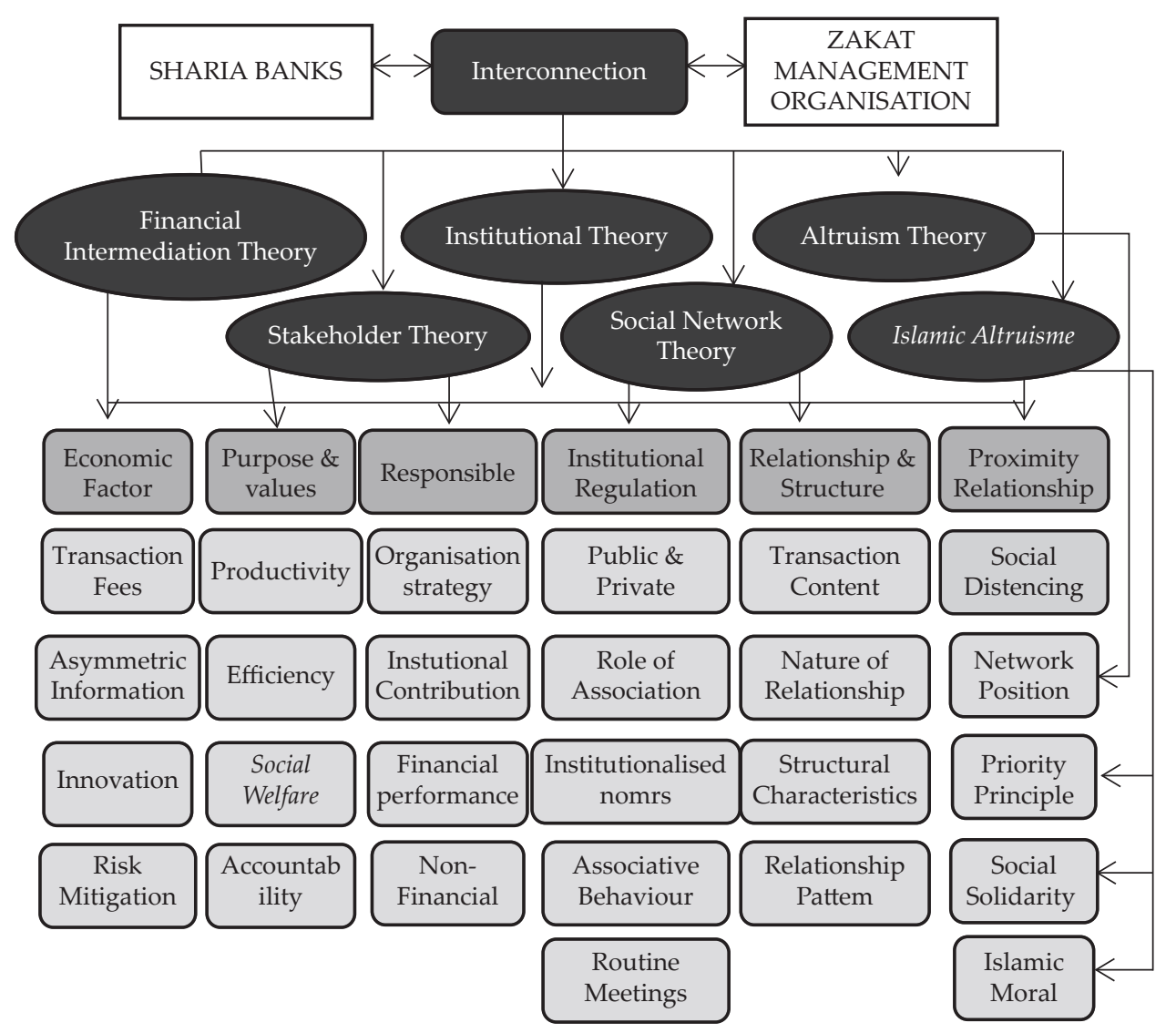

Figure 1.

\section{Conceptual Framework for the Interconnection of Islamic Banks and ZMO}

From Figure 1, it can be explained that, according to Intermediation Theory, intermediation occurs due to several factors: transaction costs, asymmetric information, innovation and risk mitigation. Meanwhile, Stakeholder Theory asserts the importance of the company implicitly and explicitly displaying elements related to company objectives and management responsibility. Furthermore, in Institutional Theory, companies are bound by public and private regulations, the presence of non-governmental and independent organisations, institutionalised norms, associative behaviour among companies, organised dialogue between companies and stakeholders, and company perspectives in carrying out social activities - whether these are instrumental, political, integrative or concerning ethics.

On the other side, Social Network Theory considers transactional content, the nature of relationships, structural characteristics and overall patterns of relationships, including homophily, heterophily and a bridge of functional participation. The theory of altruism in networks, meanwhile, states that the company has an altruistic value in carrying out its role following social distancing and network position. This includes both physical and non-physical assistance, 
social, appreciation and actualisation. The Islamic perspective on altruism is based on the principle of priority for the public interest, social solidarity and moral values.

In terms of the relationship between the variables of these theories, it can be stated that roles may be distributed between the two institutions because both Islamic banks and ZMO have relatively similar interests. This is in line with a perspective developed by Freeman, Wicks, and Parmar (2004) where both institutions require high trust and support from the public. Therefore, social contracts become relevant in maintaining their social reputation in the community and are also institutionally relevant to enable both institutions to synergise (Campbell, 2007) and then build social networks to bridge the interests of the stakeholders (Rowley, 1997), all based on altruism to carry out their roles and functions to complement each other (Bourles \& Bramoulle, 2013).

\section{METHODOLOGY}

After referring to previous research and the need for objective research, this study employs a series of methods that were considered. These include selecting the form of research, organising the data and methods of analysis, and using quantitative and qualitative approaches.

Quantitatively, this research uses the Shell Group Method of Data Handling $(\mathrm{GMDH})$ as, when it comes to data mining, this is an appropriate tool for showing the correlation between $\mathrm{ZMO}$ and Islamic bank transactions. GMDH is a global innovative provider of predictive analytics solutions and the best artificial Neural Network solution, which provides accurate and flexible forecasting for business (2020).

According to Yefimenko (2018, pp. 254-257), among the various tools for modelling methods such as Analog Complexing and fuzzy logic, GMDH is one of the most effective. GMDH makes it possible to build linear and nonlinear, static and dynamic time series models, multi-input and output. The output of a model from GMDH can also be represented both in analytical form and graphically, which reflects the interconnections of the system structure.

This study then used a qualitative approach to understand these interconnections, conducting a series of phenomenological interviews with key informants as an essential means of confirmation. Regarding the results of the data processing and interviews, the research then undertook theoretical exploration as it sought to strengthen the ideal formulation of the interconnection model of the two institutions.

\subsection{Data}

In Indonesia, there are 14 fully fledged Islamic Banks (BUS), 20 Islamic Business Units (UUS) and 168 Islamic Rural Banks (BPRS). While the number of Zakat Management Organisations (ZMO) stands at 572, consisting of 491 BAZNAS and 81 Zakat Institutions (LAZ, next will called ZI). However, if we consider the existence of Law No. 23 of 2011 on Zakat management, out of 26 National ZI, the only Islamic bank that has a national $\mathrm{ZMO}$ and periodically provides a report to 
BAZNAS is Bank Muamalat Indonesia (BMI) with Baitulmaal Muamalat (BMM) as its affiliate zakat institution, which manages zakat and other social funds totalling around 80 billion rupiahs in 2017.

The selection of Islamic banks that have a national-level ZMO is intended to ensure the results of the analysis have a significant impact and can be considered by decision-makers. It does not rely on Islamic banks' level of zakat collection, which remains limited. For instance, Bank Syariah Mandiri collected 61.515 billion rupiahs in 2019, accounting for only $1.65 \%$ of the National Zakat accumulation.

At a practical level, several zakat institutions are currently affiliated with commercial banks. Some of these are even conventional ones, namely Baitul Maal Muslims (BAMUIS) BNI affiliated with BNI, Mandiri Amal Insani (MAI) Foundation affiliated with Bank Mandiri, Yayasan Baitul Maal (YBM) BRI, which became the collector for Zakat Bank BRI, LAZNAS BSM Umat with Bank Syariah Mandiri, and Baitulmaal Muamalat with Bank Muamalat Indonesia. However, based on Presidential decree No. 8 of 2001, BAZNAS is confirmed as the institution that is authorised to undertake the management of zakat nationwide. This includes providing recommendations for the formation of BAZNAS province, Regency/city and ZI.

Referring to BAZNAS regulation number 2 year 2014 about the guidelines on how to grant permits for the establishment of the Amil Zakat Institute, and Decree of the Minister of Religious Affairs No. 333 year 2015 on guidelines for granting the establishment of Amil Zakat Institute, not all zakat management agencies can be directly registered at BAZNAS.

The only zakat institution that is a member of the Zakat Forum at the national level, and is also registered in the data of the National Amil Zakat Institute at BAZNAS, and directly affiliated with an Islamic bank, is Baitulmaal Muamalat (BMM). BMM is a zakat management agency established by Bank Muamalat Indonesia (BMI) in 2000, while in 2016, it became the national LAZ by Decree of the Minister of Religious Affairs No. 256. The institution has also played a role as an Indonesian Micro Mediator, Laznas Plus, and as a Mediator in the development of Baitul Maal wa Tamwil (BMT) in Indonesia.

In terms of its organisational structure, the Foundation board and executive directors of BMM are employees of BMI. As stated in the annual report, BMM is a BMI Association and affiliate entity. The rebranding of BMI includes BMM as its sister entity. Taking a role in micro-economic empowerment, BMI has formed a management unit of zakat, Infak and has run a charity fund and social welfare fund known as Baitulmaal since 1994. On 16 June 2000, this unit was inaugurated as the foundation of Baitulmaal Muamalat.

\subsection{Hypothesis Testing of the Interconnection}

The first stage of this research is to assess the relationship between the variables using hypothesis testing. The hypotheses used in this research are:

$\mathrm{H}_{0}$ : There is no correlation between Bank Muamalat Indonesia and Baitulmaal Muamalat at a strong level.

$\mathrm{H}_{1}$ : There is a correlation between Bank Muamalat Indonesia and Baitulmaal Muamalat at a strong level. 
Based on the results of the correlations, further analysis is then carried out to determine the effect of the account variables that have a high correlation. This is important in order to find and evaluate empirical evidence of the interconnection between the two institutions. The following regression hypotheses are applied to the findings:

$\mathrm{H}_{\mathrm{a}}$ : There is no influence between account variables at Bank Muamalat Indonesia and Baitulmaal Muamalat.

$\mathrm{H}_{2}$ : There is an influence between account at Bank Muamalat Indonesia and Baitulmaal Muamalat.

\subsection{Method}

This research conducted a series of analyses covering 3 (three) stages. First, it explored the possible interconnected factors between Islamic banks and ZMO by considering an elaborative theoretical framework from the perspective of motivation and conflict to understand the basic concepts, roles and functions of the two Islamic financial institutions. The object of research was the population of Islamic banks and ZMOs in Indonesia that manage zakat collection and distribution with systematic and integrated linkage at the national level. Since not all Islamic banks have their own ZMO at the country level, and referring to data from BAZNAS, the study simply selected BMI and BMM as the chosen research object.

The quantitative research in this research carried out the following procedures:

a. Data were taken from the financial reports of Bank Muamalat Indonesia and Baitulmaal Muamalat for 5 financial periods from 2013 to 2017. This included Statements of Financial Position, Comprehensive Profit / Loss Statements and Reports of Sources and Distribution of BMI Zakat Funds, as well as Reports on the Sources and Use of BMM Funds, a total of 85 interrelated account variables.

b. From the financial statements, 85 variables were taken, consisting of 57 accounts of BMI and 28 accounts of BMM which were selected purposively based on the relationship of the transactions between the two institutions.

c. From the results of the correlation processed using the Shell Group Method of Data Handling (GMDH), only those account variables showing a very strong correlation were taken.

d. Account variables that had a very strong correlation value were then processed using GMDH Shell, to obtain the regression classification.

e. The regression results obtained from GMDH Shell processing became the initial data to be confirmed in interviews with related parties (key informants) as a form of elaboration of the research results and to obtain more comprehensive conclusions.

After the data had been processed and a network pattern obtained from the relationship between accounts that reflected the interaction of the transactions between the two institutions, the analysis continued with the clustering of strongly correlated factors. It was especially important to reconfirm this classification in interviews with key informants at a later stage.

During the second stage, analysis was carried out by transcribing interviews with the key informants through hyper post-phenomenology procedures. This 
was applied both to the leadership and SSB of the Islamic banks and ZMO as body one and when analysing the opinions of BI, KNEKS, observers and associations as body two as one unit and regulators.

The next stage considered the formulation of the ideal model. Taking into account the quantitative results of the GMDH statistics and phenomenological interviews, the study sought to conclude integrally on the evaluation of the interconnections that had taken place and make critical recommendations for future relationship development.

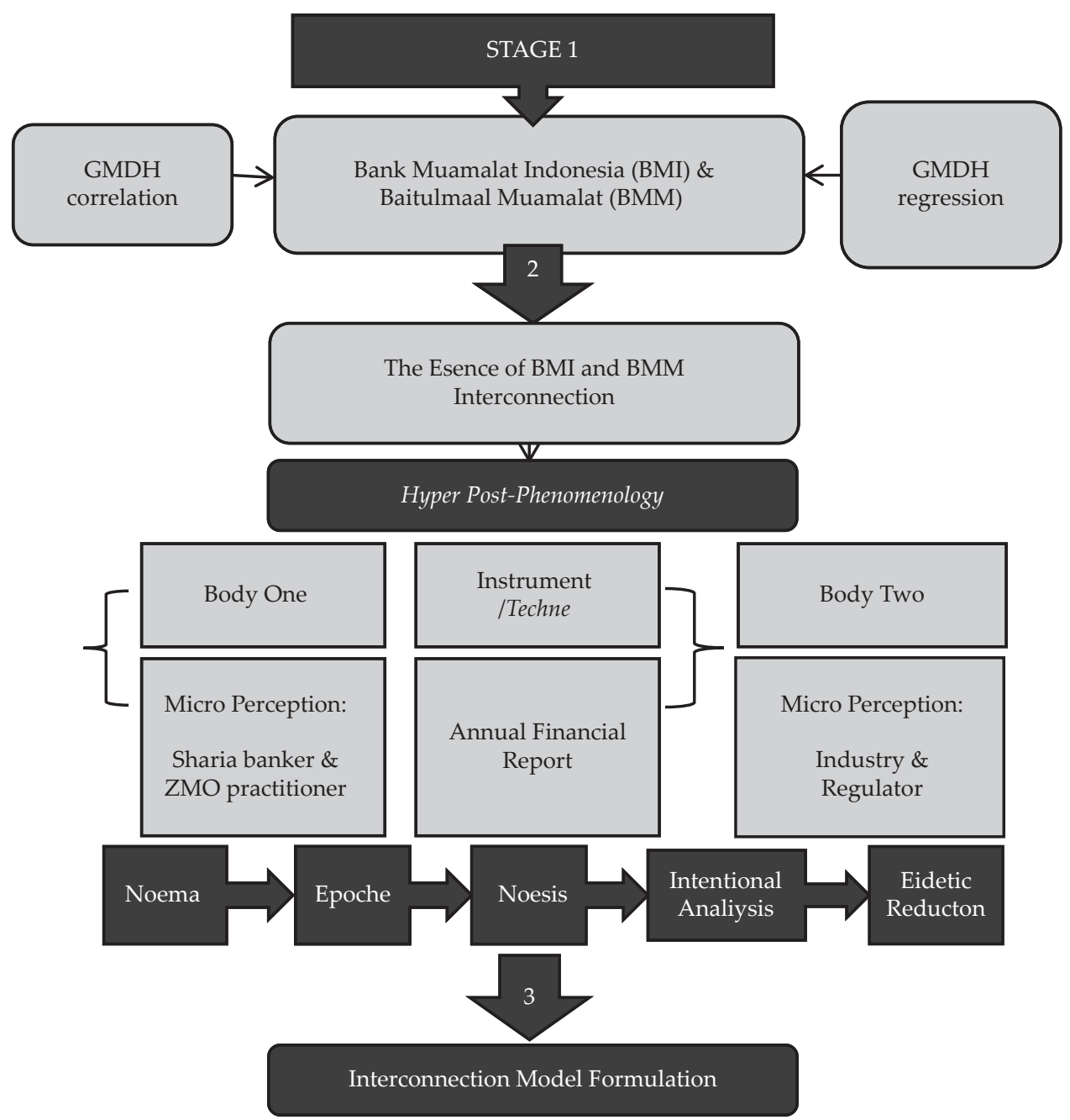

Figure 2.

Research Flow 
Comprehensively, this research is supported by transcription data obtained by listening to the opinions of key informants. At the micro level, this includes interviews with the Director of BMI, Executive Director of BMM and the Islamic Supervisory Board of BMI and BMM. On the macro side, there are opinions from Islamic Banking Observers, the Chairman of the Zakat Forum, Bank Indonesia and the Director of the National Islamic Finance Committee (KNKS - now KNEKS), to obtain a more integral analysis in understanding the phenomenon of the interconnection of Islamic banks and ZMOs in Indonesia.

\section{RESULTS AND ANALYSIS}

Bank Muamalat Indonesia, which was founded on November 1, 1991, was a pioneer in Islamic finance. However, its performance has declined over time, with increasingly non-performing financing and decreasing net profit since 2017. Nevertheless, BMI has remained consistent in carrying out its social responsibilities and positioning CSR as its goodwill and good initiative beyond the law. BMI acts ethically, supporting the community's economic development with capital investment and in conjunction with stakeholders. Implementation of the programme is done both independently, in a consortium, and synergistically with BMI's LAZ affiliates, BMM, and other local empowerment partners and other LAZ. This indicates that despite the challenges experienced by the commercial function, the social function continues to operate.

In order to understand the relationship between BMI and BMM, it needs to be considered more in terms of the related transactions between the two. One tool capable of providing a quick overview of the connected transactions is the presented financial statements. These are mentioned in the Indonesian Islamic Banking Accounting guidelines (PAPSI) as a form of management accountability for the trust of the resource management entrusted to the entity. The transactions included cover not only commercial business activities but also non-commercial social activities.

Bank Indonesia Circular Letter Number 15/26/DPbS regarding the implementation of PAPSI in 2013 asserts the obligation of all Islamic banks to implement these guidelines in the preparation of their reports and facilitate the parties to perform comparisons and evaluation of the performance of the institution from the information presented. It is important to refer to the implementation of PAPSI because the guidelines act as a reference that can help in evaluating the implementation of the function of each Islamic bank. The banks have functions not only as managers and investment agents, investors and financial providers, but also as a social-function traveller. This is mentioned in point 07 , which specifically contains information on the fulfilment of banks' social function obligation, including the acceptance and distribution of zakat, and the management of Infak, charity and Waqf funds.

Therefore, this study uses research variables that cover every account deemed to represent transactions related to both institutions in the financial activities conducted, either directly or indirectly. Data were obtained from the financial statements of BMI and BMM covering a period of 5 (five) years from 2013 to 2017. This includes accounts on the financial position report (BMI and BMM), 
comprehensive income statement (BMI), the source and use of Zakat (BMI) reports and the Fund Change report (BMM), with a total of 85 representative variables consisting of $58 \mathrm{BMI}$ accounts and $27 \mathrm{BMM}$ accounts.

The data were then processed to determine the interconnection networks between the variables associated with each other. Based on the result of the processing with GMDH Shell software, 1566 interconnected transactional relationships were identified, with both positive and negative correlates, ranging from very low to very strong correlations. This shows that statistically there is a connection between the transactions as reflected by the account variables examined in BMI and BMM, as well as descriptively through the existence of interconnections in the form of transactional relationships.

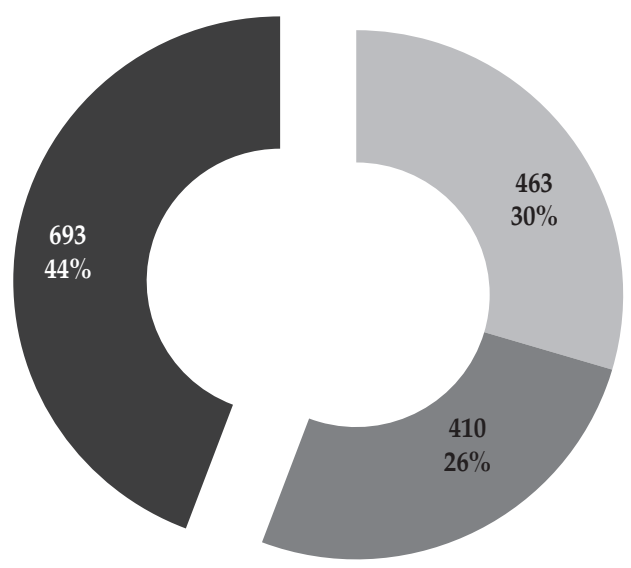

Source: Result from GMDH Shell, 2019.

Figure 3.

Correlation of BMI and BMM Accounts

From Figure 3, it can be explained that there is a close relationship between $\mathrm{BMI}$ and BMM, as reflected in the existence of 463 transactions with a strong and very strong correlation greater than 0.7 . While the predominant correlation of $44 \%$ is a medium correlation, and applies to as many as 693 accounts, the remaining $26 \%$ have low and very low correlations, representing a total of 410 accounts. Only 5 (five) of the 85 accounts studied were found to have no correlation at all. This means that, from all the account variables, several transactions were not related at all. Finally, in general, it could be concluded that there is a relationship between $\mathrm{BMI}$ and $\mathrm{BMM}$ through a representative account that is processed by more than 1500 correlations. 


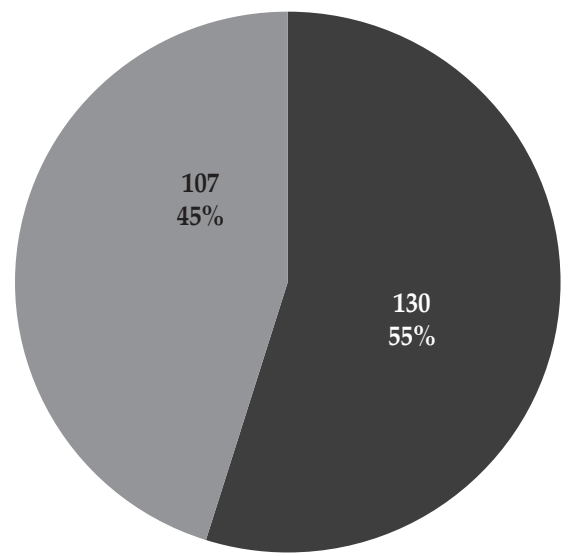

Source: Data Processed GMDH Shell, 2019.

Figure 4 .

Very Strong Correlation between BMI and BMM

As explained earlier, the interconnection has more requirements than regular relationships. A variable can be stated as having interconnections with the other new variables if a very close relationship exists between them (i.e. they are closely connected). Based on the transactional relationship data above, there is a need for further study in terms of how many accounts are included in the criteria. Referring to the results of the neural network processing, the data obtained show that 237 accounts have a correlation above 0.8 , which means there is a very strong relationship between these accounts. It was also found that as many as 130 accounts, or more than half (55\%), have a very strong negative correlation, while the remainder (45\%), i.e. 107 accounts, show a very strong positive correlation.

\subsection{Coefficient of Determination}

The interconnection between the account variables for BMI and BMM then leads to the question of how many account variables are affected by these very strong relationships, on both the BMI and BMM sides. Using the GMDH Shell device, it was determined that there were 15 accounts whose impact on other accounts could be analysed since they had a coefficient of determination value of more than 0.5 , with the details given in Table 1.

Network simulation also provides a summary of the very close two-way relationship (closely connected) between BMI and BMM. There are at least 5 (five) interconnection patterns between the Infak fund balance (MS2), the acceptance of the managed funds (MP5), retained Earnings (IE4), placement with other banks (IA4), and acceptance of Infak funds-related parties (MP3), with the fund balance of Zakat (MS1). The GMDH results also indicate the influence of BMI 'profit balance' and 'Amil' Fund balance (MS4) of BMM 'cash and cash equivalents' of 1 (one) rupiah in the first period. 
If it is assumed that the existing profit balance and Amil fund balance reach 10 billion rupiahs, it will increase by 61.60 rupiahs, which is the same as the increase in 'Musyarakah financing'. Besides, a positive influence was also found between the 'related parties Infak funds' to 'Simpanan-Giro Wadiah', which increased from 0.01 in 2013; if the value of 10 billion rupiahs, it will affect by 2.02. It is predicted that this occurs due to the acceptance of Infaq funds from related parties that will be placed on the account of deposits in the form of Giro Wadiah.

The same thing was found to occur in respect of BMI 'Placement in another Bank' transaction and 'another acceptance' of BMM, amounting to 0.01 rupiah. When the value reaches 10 billion, BMI 'immediate liabilities' will increase to 11,817 rupiahs and affect 'another acceptance' of BMM with the same value. This is because if the placement in the other bank is carried out in cooperation with a conventional bank, then the Giro service received by BMM is a Non-Halal fund, which will be submitted to the distribution entirely to BMM.

Table 1.

Variables with a Coefficient of Determination $>0.5$

\begin{tabular}{|c|c|c|c|}
\hline Variable & $\begin{array}{c}\text { Coefficient of } \\
\text { Determination (R2) }\end{array}$ & Correlation & Model \\
\hline IA8 & 0.909790 & 0.963030 & $\mathrm{Y} 1=-5.74215 \mathrm{e}^{08+\text { cycle }^{*} 1.15525}$ \\
\hline IA9 & 0.998116 & 0.999115 & $\mathrm{Y} 1=1.1276 \mathrm{e}^{08+\text { cycle }^{*} 0.995804}$ \\
\hline IA15 & 0.721328 & 0.871559 & $\mathrm{Y} 1=-7.23672 \mathrm{e}^{08+\text { cycle } 0.779457}$ \\
\hline IU1 & 0.831194 & 0.929443 & $\mathrm{Y} 1=3.1447 \mathrm{e}^{07+\text { cyde }^{4} 1.06809}$ \\
\hline IU3 & 0.723074 & 0.881882 & $Y 1=-3.3913 e^{09+\text { cycle }^{*} 1.61589}$ \\
\hline IU4 & 0.994426 & 0.997237 & $\mathrm{Y} 1=1.05432 \mathrm{e}^{09+\text { time }^{*} 4.1445 \mathrm{e}+08}$ \\
\hline IU8 & 0.759009 & 0.872408 & $\mathrm{Y} 1=-4.67326 \mathrm{e}^{08+\text { cycle }^{* 1.35018}}$ \\
\hline ID1 & 0.558828 & 0.759475 & $\mathrm{Y} 1=-2.35715 \mathrm{e}^{07+\text { cycle }^{*} 0.696102}$ \\
\hline IP3 & 0.514389 & 0.720008 & $\mathrm{Y} 1=2.90434 \mathrm{e}^{07+\text { time }^{*} 3.72686 \mathrm{e}+0}$ \\
\hline IP7 & 0.946555 & 0.974128 & $\mathrm{Y} 1=3.748 \mathrm{e}^{07+\operatorname{cyc} c e^{x} 0.935517}$ \\
\hline MA1 & 0.955317 & 0.978019 & $\mathrm{Y} 1=-4.31092 \mathrm{e}^{09+\text { cycle }} \mathrm{e}^{*} .00991$ \\
\hline MS1 & 0.968982 & 0.985155 & $\mathrm{Y} 1=1.55571 \mathrm{e}^{10+\text { time }} \mathrm{e}^{* 9.32126 \mathrm{e}+0 \mathrm{~s}}$ \\
\hline MS3 & 0.760916 & 0.883395 & $\mathrm{Y} 1=-1.19685 \mathrm{e}^{09+\mathrm{cycle}^{* 1} 1.23635}$ \\
\hline MS4 & 0.830754 & 0.918984 & $\mathrm{Y} 1=-8.96512 \mathrm{e}^{08+\text { cycle }^{*} 1.24988}$ \\
\hline MP9 & 0.893403 & 0.945557 & $\mathrm{Y} 1=-1.7433 \mathrm{e}^{08+\text { cycle }^{*} 0.919899}$ \\
\hline
\end{tabular}

Source: Result of GMDH Shell, 2019.

The receipt of fund management is also statistically proven to have the effect of 1 (one) rupiah to 'miscellaneous assets', 'Wadiah savings' and 'received loans'. With a change of increase of 6.15 while its value increases to 10 billion rupiahs. This happens because the management funds given are categorised into 3 (three) transactions on the BMI account due to their relatively large value, before finally being used by BMM in the long-term distribution of the programme.

Unlike the effect of the 'Infak fund balance', which still has a negative value in the first period of 0.01 , if the amount increases by 10 billion, it will change to a positive effect on 'Mudharabah financing', 'DST-Non-Bank Giro Mudharabah', 'Revenue from Ijarah' and 'other operating incomes', reaching 6.15. The condition 
therefore indicates that the current funds have not yet shown an ideal point and need to be continuously optimised in terms of their acceptance and management, in order to have a greater impact on Islamic banking activities.

\subsection{Social-Commercial Interconnection Analysis}

Indonesia experiences difficulties in managing its social funds, meaning it requires an integrated institution for the management of zakat that is integrated effectively, efficiently and accountably. The recommendation is to have an Islamic banking institution that has (2) two functions, namely as an intermediary for funding from profit business and as a social religious intermediary institution such as amil zakat institutions, which are formed as a rational basis for Zakat Bank.

The Law of Republic of Indonesia No. 38 of 1999 states that zakat institutions can cooperate with Islamic banks in collecting zakat assets from muzaki when banks receive requests from them. Unfortunately, the rules of commercial banks as partners for amil zakat bodies are not considered to run optimally; in Law No. 21, the government and parliament focus on Islamic banks when stating that Islamic banks and Islamic business units can carry out their social functions in the form of Baitul Maal institutions that receive zakat funds, donations, grants and other social funds and then channel these to institutions that manage zakat.

On the one hand, Islamic banking is seen as a new and promising institution in its role as an alternative source of financing for SMEs. On the other hand, zakat institutions are also permitted to provide zakat funds to MSMEs based on Zakat Law No. 38/1999, which allows this based on the productive sector (regulated in the Ministry of Religion Regulation No. 581/1999). The intention is for the poor and needy to be able to survive in difficult conditions while increasing the zakat fund benefits for others. Thus, there is a multi-faceted relationship between Islamic banks, microfinance and zakat institutions that can be developed consistently as a greater goal, with zakat as a source of funding.

The Islamic Bank and ZMO regulations have their own legal standing, although, in some aspects, the two meet at the same point. According to Islamic Banking Law No. 21/2008, Islamic banks aim to support the implementation of national development that increases justice, togetherness and the equitable distribution of people's welfare. In line with this, in the Law of the Republic of Indonesia Number 23 of 2011 concerning Management of Zakat, zakat is also seen as a religious institution that aims to improve justice and the welfare of the community and to increase its usefulness and beneficial results.

Islamic Banking Law also mentions that Islamic banks and UUS can carry out social functions in the form of Baitul Mal institutions. Otherwise, $\mathrm{ZMO}$, in zakat management law, include the National Amil Zakat Agency (BAZNAS), which manages zakat nationally; Amil Zakat Institutions (LAZ), which are formed by the community with the task of assisting in the collection, distribution and utilisation of zakat; and the Zakat Collecting Unit (UPZ), which is an organisational unit formed by BAZNAS to help collect zakat.

The purpose of zakat management, referring to article 3 of Law No.23 / 2011, is to increase the benefits of zakat in the context of realising community welfare and poverty alleviation. Improving the welfare of the community is also the responsibility of the banking industry, as referred to in Banking Law Number 
10 of 1998. It states that the main function of the Indonesian banking sector is as a collector and distributor of public funds, to support the implementation of national development and improving the welfare of the people at large.

The interviews conducted with the BMI Director, BMM Executive Director and BMI Islamic Supervisory Board (DPS) of BMI and BMM provide an overview of the existence of a mutually beneficial relationship (symbiotic mutualism) between $\mathrm{BMI}$ as a bank that tends to be commercially oriented, and BMM which has a social motivation in its operational activities. In the process of collecting zakat, infaq and other social funds, BMI was found to have an impact on the operational aspects of BMM both financially and non-financially, although there are some differences in perceptions when interpreting the interconnection between the two institutions. Despite this, it should serve as a reference for other financial institutions to optimise their respective roles.

External parties also made efforts to interpret the role of the two institutions in bridging the social and commercial sides, reporting a result that was strongly influenced by several factors, starting from the motives of investors or shareholders, management understanding and regulatory demands. In detail, it is mentioned that measuring the performance of an Islamic bank that still uses conventional indicators acts to trigger immovability with regard to the Islamic bank's intention to optimise the social role it carries. The growth of Islamic banks, which is always overshadowed by conventional institutions and the industry as a whole, has also encouraged investors to force directors to manage Islamic banks by focusing more on increasing profits.

Some have argued that Islamic banks should have a special section so that they exist not solely to seek profit from customers but also act to provide more services in the form of facilities to channel the social needs of customers. Therefore, the funds owned are used both materially and non-materially in the form of spiritual satisfaction, which is referred to as substantive Islamic and not merely administrative Islamic. This would provide a special advantage that can be used to compete with conventional banks, which provide the intended material benefits.

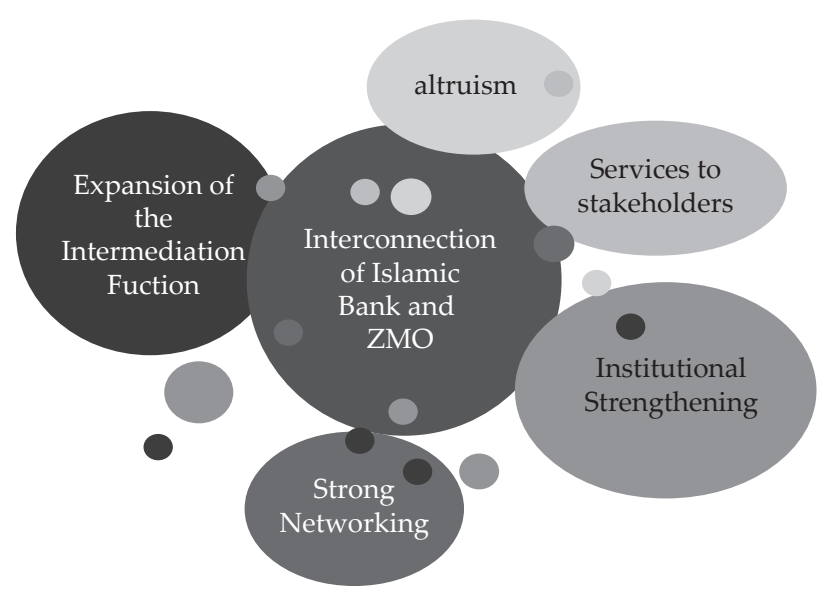

Figure 5.

Social-Commercial Interconnection between Islamic Bank and ZMO in Indonesia 
The existence of $\mathrm{ZMO}$ affiliated with Islamic banks is therefore interpreted as an effort to overcome this shortage. Regarding the implementation of social responsibility, this research has tried to conduct a study using various levels of theoretical approaches (multi-level theoretical models), namely the theory of intermediation, interests (stakeholders), institutional theory, social networks (social networks) and altruism. These five theories are tested through a series of indicators that reflect their existence in the practices and views of the speakers.

\subsubsection{Expansion of the Intermediation Function}

Intermediary theory illustrates that the affiliation between Islamic banks and $\mathrm{ZMO}$ occurs, according to the interviewees, because of transaction costs that are considered more efficient. Islamic banks and ZMO have different navigation on the implementation of the values adhered to within the company's goals. Almost all sources interpreted the objectives of Islamic banks from a more dominant commercial side with, as a consequence, little space for social aspects that are not yet considered mandatory. This differs from the objectives of $\mathrm{ZMO}$, which are completely social in nature. It is also considered to have had a significant impact on the empowerment of mustahik in the long run and has become a distinct advantage for $\mathrm{ZMO}$ because it has succeeded in providing more benefits for the progress of mustahik.

\subsubsection{Services to Stakeholders}

Affiliation between Islamic banks and ZMO is also interpreted as an effort to improve the current efficiency of both institutions. Bank facilities that can be used by $\mathrm{ZMO}$, including offices, human resources and other facilities, offer a means of reducing the high operational costs earlier. The aspects of social welfare can be obtained by the two institutions via synergy that is well built through the means of affiliation, thereby yielding benefits for both. The bank, as a financial institution that also has a mandate to encourage the development of the micro sector, can carry out its role, even before the micro business is deemed worthy of financing.

In practice, however, this affiliation model often collides with its accountability aspects. Interventions that cannot be avoided often occur because the parent institution has an interest in controlling the institutions it establishes (i.e. those under its control). Almost all of the interviewees agreed on this aspect, providing various recommendations. These included the assertion to grant full authority to the management to manage the existing social funds for the interests of the community in accordance with established procedures.

It is the responsibility of the management to ensure professionalism and governance and that the institutions provide full benefits to interested parties and conduct their operations according to Islamic objectives (maqashid). This duty then serves as a test for the management, as well as regulators, to submit to the interests of one party or the community at large.

In terms of market share, BMI realises that it does not hold an optimal share to support the economy as neither its profits nor its zakat contribution are rising. Islamic banks have also been criticised for focusing more on profits 
than intermediation as their surroundings demand they are always compared to conventional banks. However, Islamic banks have achieved above-average growth in the industry and continue to make a steadily growing contribution. Therefore, the positive correlation of commercial contributions channelled to society has had an impact on financial performance both directly and indirectly. The distribution of zakat and other social funds has also had an impact on BMI's non-financial performance in the form of a good reputation, customer and employee loyalty, and increased public awareness.

\subsubsection{Institutional Strengthening}

From an institutional perspective, there is a need to support public and private regulations to optimise the interconnection of the two institutions. These begin with changes in the parameters of the health level of Islamic banks, which include social targets of a few per cent of their performance, stimulus tax cuts and permission for Islamic banks to also play a role as nadzirs and managers of zakat (amil). This is interpreted as a form of political will that illustrates the needs of Islamic banks seeking special supervision, which differs from conventional banks because of the different roles and functions that they perform. According to the informants, the OJK position is interpreted to comprise commercial demands.

The presence of non-governmental and independent organisations is also expected to bring together the synergy of the two institutions. This includes the role of the Zakat Forum (FOZ) to enhance collaboration, build capacity (capacity building) and initiate change as the role of BAZNAS and KNEKS, which will strengthen synergy and coordination. Associatively, behaviour among companies is also not yet seen as providing support for integration. On the one hand, Islamic banks continue to focus on and have difficulty pursuing the conventional ones. This is worsened by the low level of support given to ZMO as seen from LAZ accounts, which are not all Islamic. Meanwhile, not all banks follow the BMI-BMM pattern. As such, this synergy will become a form of mission change that will also encourage other behavioural changes. These will include consideration of whether to accord DPK customers the right to have the same authority as the capital owner.

According to the interviewees, at present, no specific discussion has taken place between the two institutions and other institutions aimed at initiating synergies between their roles. There is no discourse of convergence in $\mathrm{ZMO}$, also synchronisation with banks. In interpreting the relationship between Islamic banks and $\mathrm{ZMO}$, an interesting point to consider is that Islamic banks assess the existence of affiliated LAZ as creating a very strong positive image for the company (i.e. brand image) as a form of shareholder politics. This is because the ZMO affiliate option is considered more profitable in terms of added value and also attracts the interest of other parties, with the hope of building support for Islamic banks among various other parties. This occurs alongside being a form of social duty and the spirit of service as expected by KNEKS, as suggested by the Director of BMI. 


\subsubsection{Strengthening the Network}

The close relationship between the two institutions is reflected in the content of transactions in the form of zakat collection by Islamic banks, which is the largest source for affiliated ZMO. This includes benefits in the form of service network synergies, the distribution of good funds and other managed funds that cannot be carried out directly by Islamic banks because they are hampered by regulations. In the future, this relationship will also be expanded by synergy in financing (blended finance) in which zakat is used as funding for micro-businesses to enter the bankable phase. Besides running its function with a transactional relationship in the form of the deduction of zakat directly from Islamic bank accounts owned by Muslims, and the opening of Islamic bank accounts for assistance to the needy, as initiated by KNEKS.

The nature of the link is a symbiotic mutualism. Islamic banks act as the largest source of funds for ZMOs, in addition to providing network completeness and other facilities. Islamic banks also receive benefits in the form of a stronger brand, while the need for control and the reasons for regulations permitting only banks to collect zakat means that $\mathrm{ZMO}$ affiliates are required to channel the affiliation in order to realise the initiation of empowerment and long-term permanent business units in the form of micro banking, which in time will also benefit Islamic banking itself.

Clarity of expectation of this affiliation is also interpreted as a form of ecosystem preparation, improved governance, distribution standards and databases, as well as expansion opportunities. These sit alongside prerequisites for changes in community behaviours, the Islamic literacy of management and regulator engineering to regulate paradigm changes and increase the quality of human resources and community literacy, industrial capacity and the harmonisation of policies by KNEKS.

The structural characteristics of this interconnection are alignments that bring together the business processes of the two institutions, because all BMI branches are also representatives of BMM, despite being different legal entities. Heterophily is also created due to differences in the navigation of core business and is seen in the complementary programme synergies. The majority of the patterns show its role as a bridge of functional participation (strategic collaboration) to meet the consequences of accounting and regulatory provisions related to the distribution of social funds including zakat. Where BMI is gathered, BMM is distributed. As well as the zakat data interlink, to form sustainable financing where once bankable, mustahik will get banking services.

\subsubsection{Reflection of Altruism}

Affiliated ZMO provide support to Islamic banks in the form of social activities that can be recognised as a proven form of banking performance at BMI. This has led to many awards in the field of social activities as well as a form of self-actualisation for companies as well as personal HR. This role could be enhanced using technology, with certification in the form of digital finance for the empowerment of mustahik, thus improving product quality and further optimising access to funds for microbusiness financing. It could also include enhancing the inclusiveness of Islamic 
banking, aided by an increase in the number of accounts due to this kind of institutional synergy.

As a whole, the existence of Islamic bank interconnections and ZMO can be interpreted as a form of implementation of the intermediation function, service to stakeholders, institutional strengthening, social network expansion and a reflection on institutional altruism. These five elements will form the basis for synergy between the two institutions. This could be further optimised in the future in terms of the two institutions conducting their respective roles through strategic cooperation on a large joint goal, encouraging economic growth and providing solutions to the problems of the greater community.

\section{CONCLUSION AND RECOMMENDATION}

\subsection{Conclusion}

Based on the discussion of the result above, it can be concluded that a close relationship exists that reflects the interconnection between BMI and BMM as representatives of the Islamic bank and $\mathrm{ZMO}$. The following provides a summary of the findings:

First, BMI and BMM statistically influence one another, although still at a limited and low scale. Several of the financial activities carried out by BMI, however, were found to have an impact on BMM, and vice versa. On the other side, if the number of social funds is increased, this will affect both institutions financially. Second, the essence of the interconnection between BMI and BMM contains a synergistic meaning as symbiotic mutualism. This occurs since both BMI and BMM derive benefits from accumulating zakat as their main side source of obtaining funds and optimise it to intermediate their social functions. This function is undertaken to build a positive brand image in the community, increasing added value as forms of social responsibility and service spirit. Finally, affiliation is interpreted as having a moderating influence on Islamic banks and ZMO in terms of optimising their roles as intermediators, safeguarding the interests of the stakeholders, strengthening and expanding social networks, and also as a form of altruism from an Islamic perspective.

\subsection{Recommendation}

This study makes several recommendations aimed at developing a better linkage between Islamic banks and ZMO. The first implication is to promote this model of affiliation for application and acceptance by the regulator to support its performance and increase the growth of these Islamic financial institutions. Although they have different methods of carrying out their respective business processes, with different rules and regulators, this would provide both a means and challenges for the two to collaborate on visionary and sustainable dynamic programmes. Islamic banks do not need to worry about establishing their own zakat institutions as part of their business, thus further strengthening the intermediation function of the institutions.

This study also found that the model requires a change in the owner's intention, increased community literacy, an understanding of Islamic economics at the 
management level, government participation and the need for control. Therefore, it proposes the development of a special function aligned with the parameters of Islamic bank health level measurements. For the next stage, productive zakat will become a point of differentiation for Islamic banks and become a form of strategic partnership and strong collaboration between the institutions.

\subsection{Limitation of the study}

This research sought to develop a deeper understanding of an object as a whole. However, it only obtained data from Bank Muamalat Indonesia (BMI) and Baitulmaal Muamalat (BMM) covering 5 periods. This enabled the study to specifically describe the interconnection of the objects concerned, although it was unable to generalise its findings to other Islamic financial institutions. Nevertheless, in an effort to sharpen the result, the study attempted to strengthen the basis of analysis by conducting interviews with other key internal and external stakeholders.

\section{ACKNOWLEDGEMENTS}

This publication was made possible by the award from Bank Indonesia Institute. The author is grateful to the reviewers, Prof. Dr. Raditya Sukmana and Prof. Dr. Dian Masyita, for their guidance in refining this paper. Thanks to Mr. Donny Setiawan for improving the writing and to BMI, BMM, BAZNAS, Ministry of Religion Affairs RI, STEI SEBI, UIN Jakarta, and all colleagues, for supporting this research.

\section{REFERENCES}

Abdurrahman, A. b. M. b. (2008). Tafsir Ibnu Katsir. Jakarta: Pustaka Imam AsySyafi'i.

Ahamat, A. (2017). Is Islamic banking and finance doing enough? Shaping the sustainable and socially responsible investment community. Asian Social Science, 13(3), 170-176.

Al-Haritsi, J. b. A. (2006). Fikih ekonomi Umar bin Al-Khatab. Jakarta: Khalifa.

Askari, H., Iqbal, Z., Krichene, N., \& Mirakhor, A. (2010). The stability of Islamic finance: Creating a resilient financial environment for a secure future. Singapore: John Wiley \& Sons (Asia) Pte. Ltd.

Asutay, M. (2007). Conceptualisation of the second best solution in overcoming the social failure of Islamic banking and finance: Examining the overpowering of homoislamicus by homoeconomicus. IIUM Journal in Economics and Management, 15(2), 167-195.

Asutay, M. (2012). Conceptualising and locating the social failure of Islamic finance: Aspiration of Islamic moral economy vs. the realities of Islamic finance. Asian and African Area Studies, 11(2), 93-113.

Az-Zuhaili, W. (2011). Fiqih Islam wa Adillatuh. Jakarta: Gema Insan Press.

Bank Muamalat Indonesia (2019). Laporan tahunan [Annual report]. Jakarta: BMI. 
Bank Syariah Mandiri (2019). Laporan tahunan [Annual Report]. Jakarta: BSM.

BAZNAS Center of Strategic Studies (2019). Indikator pemetaan potensi zakat [Zakat potential mapping indicators]. Jakarta: Puskas BAZNAS.

BAZNAS (2019). Statistik zakat nasional [National zakat statistics]. Jakarta: Badan Amil Zakat Nasional.

Bourles, R., \& Bramoulle, Y. (2013). Altruism in network. AMSE Working Paper 1356, Aix-Marseille School of Economics, France (pp. 1-33).

Bremer, J. (2013). Zakat and economic justice: Emerging international models and their relevance for Egypt. Third Annual Conference on Arab Philanthropy and Civic Engagement, June 4-6, 2013, Tunis, Tunisia, (pp. 51-74).

Campbell, J. L. (2007). Why would corporations behave in socially responsible ways? An institutional theory of corporate social responsibility. The Academy of Management Review, 32(2), 946-967.

Cham, T. (2018). Determinants of Islamic banking growth: An empirical analysis. International Journal of Islamic and Middle Eastern Finance and Management, 11(1), 18-39.

Chapra, M. U. (2000). Islam dan tantangan ekonomi. Jakarta: Gema Insani Press.

Chapra, M. U. (2009). Ethics and economics: An Islamic perspective. Islamic Economic Studies, 16(1\&2), 1-24.

Choudhury, M. A. (2013). Complexity and endogeneity in economic modelling. Kybernetes, 42(2), 226-240.

Choudhury, M. A., \& Harahap, S. S. (2009). Complementing community, business and microentreprise by the Islamic epistemological methodology: A case study of Indonesia. International Journal of Islamic and Middle Eastern Finance and Management, 2(2), 139-159.

Curry, O., \& Dunbar, R. (2011). Altruism in networks: The effect of connections. Biology Letters, 7(5), 651-653.

Dacin, M. T., Goodstein, J., \& Scott, W. R. (2002). Institutional theory and institutional change: Introduction to the special research forum. The Academy Management Journal, 45(1), 45-56.

Dakhori, A., Luth, T., Ruba'i, M., \& Syafa'at, R. (2014). The bank of alm (zakat): Ideas, structure, and the implementation of the integrated alm management. Journal of Law, Policy and Globalization, 25(2014), 62-71.

Dunn, W. N. (2016). Social network theory. In T. E. Backer (Ed.), Knowledge: Creation, Diffusion, Utilization (pp. 453-461). Pennsylvania: Pennsylvania State University.

Dusuki, A. W. (2008a). Understanding the objectives of Islamic banking: A survey of stakeholders' perspectives. International Journal of Islamic Middle Eastern Finance and Management, 1(2), 132-148.

Dusuki, A. W. (2008b). What does Islam say about corporate social responsibility? Review of Islamic Economics, 12(1), 5-28.

Freeman, R. E. (1994). The politics of stakeholder theory: Some future direction. Business Ethics Quarterly, 4(4), 409-421.

Freeman, R. E., Wicks, A. C., \& Parmar, B. (2004). Stakeholder theory and the corporate objective revisited. Organization Science, 15(3), 364-369.

Garriga, E., \& Melé D. (2004). Corporate social responsibility theories: Mapping the territory. Journal of Business Ethics, 53(2004), 51-71. 
GMDH (2020). About: GMDH. [Online] Available at: https://gmdhsoftware.com.

Haniffa, R., \& Hudaib, M. (2010). Islamic finance: From sacred intentions to secular goals? Journal of Islamic Accounting and Business Research, 1(2), 85-91.

Hassan, M. K., \& Lewis, M. K. (2007). Handbook of Islamic banking. Cheltenham, UK: Edward Elgar Publishing Limited.

Ismail, A. G., \& Khir, M. F. A. (2010). Debate on policy issues in the field of zakat on Islamic bank business. Penang: Universiti Kebangsaan Malaysia.

Jensen, M. C. (2001). Value maximization, stakeholder theory, and the corporate objective function. Journal of Applied Corporate Finance, 14(3), 8-21.

Jones, T. M. (1995). Instrumental stakeholder theory: A synthesis of ethics and economics. The Academy of Management Review, 20(2), 404-437.

Jouti, A. T. (2019). An integrated approach for building sustainable Islamic social finance ecosystems. ISRA International Journal of Islamic Finance, 11(2), 246-266.

Kar, M., Nazhoglu, S., \& Agir, H. (2011). Financial development and economic growth nexus in the MENA countries: Bootstrap panel granger causality analysis. Economic Modelling, 28(2011), 685-693.

Kasri, R. A., Arundina, T., Indraswari, K. D., \& Prasetyo, M. B. (2017). Bank run and stability of Islamic banking in Indonesia. Journal of Islamic Monetary Economics and Finance, 3(1), 25-60.

Kuran, T. (1997). The genesis of Islamic economics: A chapter in the politics of Muslim identity. Social Research, 64(2), 301-338.

Latief, H. (2013). Islamic philanthropy and the private sector in Indonesia. Indonesian Journal of Islam and Muslim Societies, 3(2), 175-201.

Levine, R., Loayza, N., \& Beck, T. (2000). Financial intermediation and growth: Causality and causes. Journal of Monetary Economics, 46(2000), 31-77.

Lorenzoni, G., \& Lipparini, A. (1999). The leveraging of interfirm relationship as a distinctive organizational capability: A longitudinal study. Strategic Management Journal, 20(4), 317-338.

Mahon, R. (2019). Broadening the social investment agenda: The OECD, the World Bank and inclusive growth. Global Social Policy, 19(1-2), 121-138.

Masra, Saleh, S., \& Hamid, W. (2020). Analisis kinerja keuangan ditinjau dari rasio maqashid syariah (studi kasus pada bank umum syariah di Indonesia periode 2014-2018). Jurnal Manajemen dan Kewirausahaan, 12(2), 57-69.

Meydia (2013). Studi peristiwa pengumuman kerjasama interkoneksi ATM Bank Mandiri dan BCA (16 Januari 2012) terhadap kinerja harga saham Bank Mandiri dan $B C A$ [Study on the announcement of the interconnection cooperation between Bank Mandiri and BCA ATMs (16 January 2012) on the performance of Bank Mandiri and $B C A$ stock prices]. [Graduate Thesis]. Yogyakarta: Universitas Gadjah Mada.

Mufraini, M. A. (2013). Keterkaitan kepercayaan investor dan stabilitas operasional terhadap strategi pembiayaan suatu studi pada Bank Islam di Asia [The relationship between investor confidence and operational stability on the financing strategy of a study at Islamic Banks in Asia]. [Undergraduate Thesis]. Bandung: Universitas Padjadjaran.

Muljadi (2017). Prospek baitul maal wat tamwil (bmt) dalam memajukan pengusaha mikro. Dynamic Management Journal, 1(2), 1-7.

Nor, S. M. (2016). Islamic social bank: An adaptation of Islamic banking?. Jurnal Pengurusan, 46(2016), 43-52. 
OJK (2019). Laporan perkembangan keuangan syariah Indonesia [The development of Indonesian Islamic finance report]. Jakarta: Otoritas Jasa Keuangan.

Rahayu, A. T., \& Pranowo, B. (2012). Analisis pengaruh tingkat suku bunga deposito bank konvensional terhadap deposito mudharabah pada bank syariah di Indonesia. Jurnal Ekonomi dan Studi Pembangunan, 4(1), 93-104.

Rahman, A. (1995). Doktrin ekonomi Islam. Yogyakarta: Dana Bakti Wakaf.

Rahman, A. R. A. (2007). Islamic microfinance: A missing component in Islamic banking. Kyoto Bulletin of Islamic Area Studies, 1-2(2007), 38-53.

Rowley, T. J. (1997). Moving beyond dyadic ties: A network theory of stakeholder influences. Academy of Management Review, 22(4), 887-910.

Rudnyckyj, D. (2010). Spiritual economies: Islam, globalization, and the afterlife of development. Ithaca and London: Cornell University Press.

Rusydiana, A. S. (2009). Hubungan antara perdagangan internasional, pertumbuhan ekonomi dan perkembangan industri keuangan syariah di Indonesia. Tazkia Islamic Finance \& Business Review, 4(1), 47-60.

Scholtens, B., \& Wensveen, D. V. (2003). The theory of financial intermediation: An essay on what it does (not) explain. SUERF Conference Proceedings and Studies, SUERF - The European Money and Finance Forum, No. 2003/1.

Shihab, Q. (2000). Tafsir al-Misbah: Pesan, kesan dan keserasian Al-Qur'an. Ciputat: Lentera Hati.

Siddiqi, M. N. (2005). Teaching Islamic economics. Saudi Arabia: Scientific Publishing Centre.

Siddiqi, M. N. (2006). Islamic banking and finance in theory and practice: A survey of state of the art. Islamic Economic Studies, 13(2), 1-48.

Siswantoro, D. (2008). The role of Indonesian government in enhancing Islamic financing for small and medium entreprises (SMEs). In: Islamic Finance for Micro and Medium Enterprises. Brunei Darussalam: IRTI-IDB and Centre for Islamic Banking, Finance and Management - Universiti Brunei Darussalam.

Suharto, U. (2017). Financial instability hypothesis (FIH) of Minsky: contextualizing the roles of Islamic commercial and social finance. Journal of Islamic Monetary Economics and Finance, 2(2), 145-172.

Tajuddin, T. S., \& Bahari, N. F. (2019). Exploring the quality of zakat reporting of Islamic banking institutions: Evidences from Malaysia. International Journal of Business, Economics and Law, 20(1), 27-33.

Tripp, C. (2006). Islam and the moral economy: The challenge of capitalism. Cambridge, UK: Cambridge University Press.

Yefimenko, S. (2018). Advances in GMDH-based predictive analytics tools for business intelligence systems. ACIT 2018, June 1-3, 2018, Ceske Budejovice, Czech Republic.

Yusof, R. M., \& Bahlous, M. (2013). Islamic banking and economic growth in GCC \& East Asia countries: A panel cointegration analysis. Journal of Islamic Accounting and Business Research, 4(2), 151-172.

Zafar, M. B., \& Sulaiman, A. A. (2019). CSR narrative under Islamic paradigm. Social Responsibility Journal, 17(1), 15-29. 


\section{APPENDIX}

\section{Regression Classification Model of BMI-BMM}

\begin{tabular}{lcc}
\hline Variable & Account & Classification Model \\
\hline IA8 & Pembiayaan Mudharabah & $\mathrm{Y} 1=-0.615867+\mathrm{MS}^{\wedge} 2^{*} 6.67691 \mathrm{e}^{-21}$ \\
IA9 & Pembiayaan Musyarakah & $\mathrm{Y} 1=-0.0936852+\mathrm{IE} 4^{*} \mathrm{MS} 4^{*} 6.16985 \mathrm{e}^{-19}$ \\
IA15 & Aset Lain-lain & $\mathrm{Y} 1=-0.0107689+\mathrm{MP} 5^{\wedge} 2^{*} 6.16181 \mathrm{e}^{-20}$ \\
IU1 & Liabilitas Segera & $\mathrm{Y} 1=-0.0726633+\mathrm{IA} 4^{\wedge} 2^{*} 1.18172 \mathrm{e}^{-16}$ \\
IU3 & Simpanan - Giro Wadiah & $\mathrm{Y} 1=-0.00488768+\mathrm{MP}^{\wedge} 2^{*} 2.02485 \mathrm{e}^{-20}$ \\
IU4 & Simpanan - Tabungan Wadiah & $\mathrm{Y} 1=-0.0107689+\mathrm{MP}^{\wedge} 2^{*} 6.16181 \mathrm{e}^{-20}$ \\
IU8 & Pinjaman yang diterima & $\mathrm{Y} 1=-0.0107689+\mathrm{MP5}^{\wedge} 2^{*} 6.16181 \mathrm{e}^{-20}$ \\
ID1 & DST-Bukan Bank Giro Mudharabah & $\mathrm{Y} 1=-0.615867+\mathrm{MS}^{\wedge} 2^{*} 6.67691 \mathrm{e}^{-21}$ \\
IP3 & Pendapatan dari Ijarah & $\mathrm{Y} 1=-0.615867+\mathrm{MS}^{\wedge} 2^{*} 6.67691 \mathrm{e}^{-21}$ \\
IP7 & Pendapatan Operasional Lainnya & $\mathrm{Y} 1=-0.615867+\mathrm{MS}^{\wedge} 2^{*} 6.67691 \mathrm{e}^{-21}$ \\
MA1 & Kas dan Setara Kas (BMM) & $\mathrm{Y} 1=-0.0936852+\mathrm{IE} 4^{*} \mathrm{MS}^{*} 6.16985 \mathrm{e}^{-19}$ \\
MP9 & Penerimaan Lainnya (BMM) & $\mathrm{Y} 1=-0.0726633+\mathrm{IA} 4^{\wedge} 2^{*} 1.18172 \mathrm{e}^{-16}$ \\
\hline
\end{tabular}

Source: GMDH Shell, 2019. 
This page is intentionally left blank 